\title{
Adaptive variation in physiological traits of beech provenances in Central Europe
}

\author{
Jana Kučerová( ${ }^{(1)}$, \\ Alena Konôpková(2), \\ Eva Pšidová (1), \\ Daniel Kurjak ${ }^{(2)}$, \\ Gabriela Jamnická (1), \\ Kristína Slugenová (1), \\ Dušan Gömöry ${ }^{(2)}$, \\ Lubica Ditmarová ${ }^{(1)}$
}

\begin{abstract}
Current climate changes can led to a decline of local beech populations fully adapted to previous climate conditions. In this context, the issue of variation in adaptive traits becomes important. A field experiment with 18-year-old trees of Fagus sylvatica L. was conducted on provenance plot located in Tále (Central Slovakia), where physiological responses of five beech provenances originating from contrasting sites along an altitudinal gradient from 55 to 1100 $\mathrm{m}$ a.s.l. across the range of the natural beech distribution were studied. Stomatal characteristics, parameters of chlorophyll $a$ fluorescence and gas exchange parameters were determined. Overall, we observed a significant increase in physiological performance at the leaf level with increasing altitude of origin. Provenances from the higher altitudes showed higher $\mathrm{CO}_{2}$ assimilation rate, stomatal density, potential conductance indices and photochemical efficiency, and lower capability for dissipation of energy by heat. A similar pattern of response was recorded in relation to the precipitation regime of sites of origin. Moreover, in the context of the temperature regime, several negative trends were observed.
\end{abstract}

Keywords: Adaptation, Provenance Trial, Fagus sylvatica L., Chlorophyll a Fluorescence, Stomatal Traits, Gas Exchange

changes such as the current climate change and what are the limits of human interference in this respect is still debated. The rate of adaptation of trees to environmental change depends on successful recruitment events during their lifetime, whereas only morphological and physiological adjustments allow individuals to persist in a stressful environment (Hamrick 2004). In this context, it is desirable to better understand the physiological processes that underlie growth and production, focusing on traits strongly related to biological fitness, such as photosynthesis and respiration, as well as traits relevant in the context of climate change, such as water balance, drought and heat resistance, etc. (Gömöry 2010, Wortemann et al. 2011, Stojnić et al. 2015). As changes in environmental conditions occur along altitudinal gradients even over short distances, such gradients offer a powerful experimental setup for studying the ecological response of

$\square$ (1) Institute of Forest Ecology, Slovak Academy of Sciences, Zvolen (Slovakia); (2) Faculty of Forestry, Technical University in Zvolen, Zvolen (Slovakia)

@ Jana Kučerová (jmajerova8@gmail.com)

Received: Nov 23, 2016 - Accepted: Oct 12, 2017

Citation: Kučerová J, Konôpková A, Pšidová E, Kurjak D, Jamnická G, Slugenová K, Gömöry D, Ditmarová L (2018). Adaptive variation in physiological traits of beech provenances in Central Europe. iForest 11: 24-31. - doi: 10.3832/ifor2291-010 [online 2018-01-09]

plants to changing environments. Moreover, spatial variation in functional traits along an altitudinal gradient can also illustrate the trends associated with plant responses to climate changes (Körner 2007, Read et al. 2014). Several studies have recorded the gradual changes of ecophysiological (photosynthetic capacity, stomatal conductance, water use efficiency, etc.) and morphological traits of leaves (stomatal density, leaf mass per area, thickness of leaf lamina, etc.) along an altitudinal gradient, as well as the morphologically and physiologically distinctiveness of high-altitude populations in comparison to related populations at lower altitudes (Ackerly et al. 2000, Still et al. 2005, Bresson et al. 2009, Holland \& Richardson 2009, Paridari et al. 2013, Wang et al. 2014, Chen et al. 2016).

Provenance analysis represent a potential approach to simulate the shift of climatic characteristics, allowing to assess the phenotypic responses of populations to transfer and the identification of well growing and adapted populations with higher resistance against adverse environmental factors. The aim of provenance trials is to minimize differences among different populations due to large-scale environmental effects by growing plant material of different origins under common conditions (Clausen et al. 1939). Because in provenance experiments trees grow in a different environment compared to that to which they were originally adapted, such experiments could help predict the responses of tree species to changing climates. Provenance experi- 
Tab. 1 - List of beech populations with geographical and climatic characteristics. $\left(\mathrm{T}_{\mathrm{A}}\right)$ : mean annual temperature $\left({ }^{\circ} \mathrm{C}\right)$; $\left(\mathrm{T}_{59}\right)$ : mean temperature during vegetation season $\left({ }^{\circ} \mathrm{C}\right) ;\left(\mathrm{P}_{\mathrm{A}}\right)$ : mean annual precipitation $(\mathrm{mm}) ;\left(\mathrm{P}_{59}\right)$ : mean amount of precipitation during vegetation season $(\mathrm{mm})$.

\begin{tabular}{lllccccccc}
\hline Label & Country & Name & $\begin{array}{c}\text { Longitude } \\
\text { N }\end{array}$ & $\begin{array}{c}\text { Latitude } \\
\mathbf{E}\end{array}$ & $\begin{array}{c}\text { Elevation } \\
(\mathbf{m} \text { a.s.l. })\end{array}$ & $\mathbf{T}_{\mathrm{A}}$ & $\mathbf{T}_{59}$ & $\mathbf{P}_{\mathrm{A}}$ & $\mathbf{P}_{59}$ \\
\hline Trial plot & Slovakia & Tále & $19^{\circ} 03^{\prime}$ & $48^{\circ} 63^{\prime}$ & 850 & 6.6 & 14.1 & 842 & 441 \\
26DE & Germany & Farchau & $10^{\circ} 40^{\prime}$ & $53^{\circ} 39^{\prime}$ & 55 & 8.3 & 15 & 678 & 319 \\
30DE & Germany & Belzig & $12^{\circ} 25^{\prime}$ & $52^{\circ} 03^{\prime}$ & 140 & 8.6 & 15.6 & 558 & 282 \\
39PL & Poland & Jaworze & $19^{\circ} 10^{\prime}$ & $49^{\circ} 50^{\prime}$ & 450 & 6.3 & 13.9 & 903 & 533 \\
55SI & Slovenia & Postojna Javor & $14^{\circ} 21^{\prime}$ & $45^{\circ} 44^{\prime}$ & 1040 & 8.1 & 15 & 1345 & 586 \\
36AT & Austria & Eisenerz & $14^{\circ} 51^{\prime}$ & $47^{\circ} 32^{\prime}$ & 1100 & 2.9 & 10 & 1168 & 648 \\
\hline
\end{tabular}

ments have shown that tree species are able to cope with a wide range of environmental conditions. It is likely that seasonal acclimation dynamics is an important element of adaptation (Beuker et al. 1998).

European beech (Fagus sylvatica L.) is the main species of deciduous forests in Central Europe. It represents the most competitive tree species on sites with moderate soil moisture and acidity, widespread across this region (Bohn 2004). Because beech is an important timber species in Central Europe, it is essential to guarantee the vitality and productivity of future beech stands. In the context of the predicted changes in annual distribution and amount of precipitation, beech stands are considered endangered due to their relatively high drought sensitivity.

The main aim of this study was to assess the adaptive variation in physiological traits of beech provenances in relation to environment of their origin, which refers to adaptation of provenances by natural selection over generations.

\section{Material and methods}

\section{Experimental material}

A large provenance experiment with European beech (Fagus sylvatica L.) was established in 1998 under the coordination of the Federal Forest Research Centre, Institute of Forest Genetics in Grosshansdorf, Germany, using two-year-old seedlings. In situ measurements and samplings were conducted in July and August 2014 on the trial plot located in Tále (Central Slovakia $48^{\circ} 38^{\prime} \mathrm{N}, 19^{\circ} 02^{\prime} \mathrm{E}$, elevation $810 \mathrm{~m}$ a.s.l.). The plot is situated in a region characterized by moderate climate conditions, at the natural climatic optimum of beech distribution (Tab. 1). The design of the experiment included three completely randomized and continuous blocks. Each block included initially 50 plants planted at $2 \times 1 \mathrm{~m}$ spacing (Gömöry et al. 2015).

Five provenances of European beech originating from different climatic regions were selected for the trial (Tab. 1, Fig. 1). All the selected provenances originated from

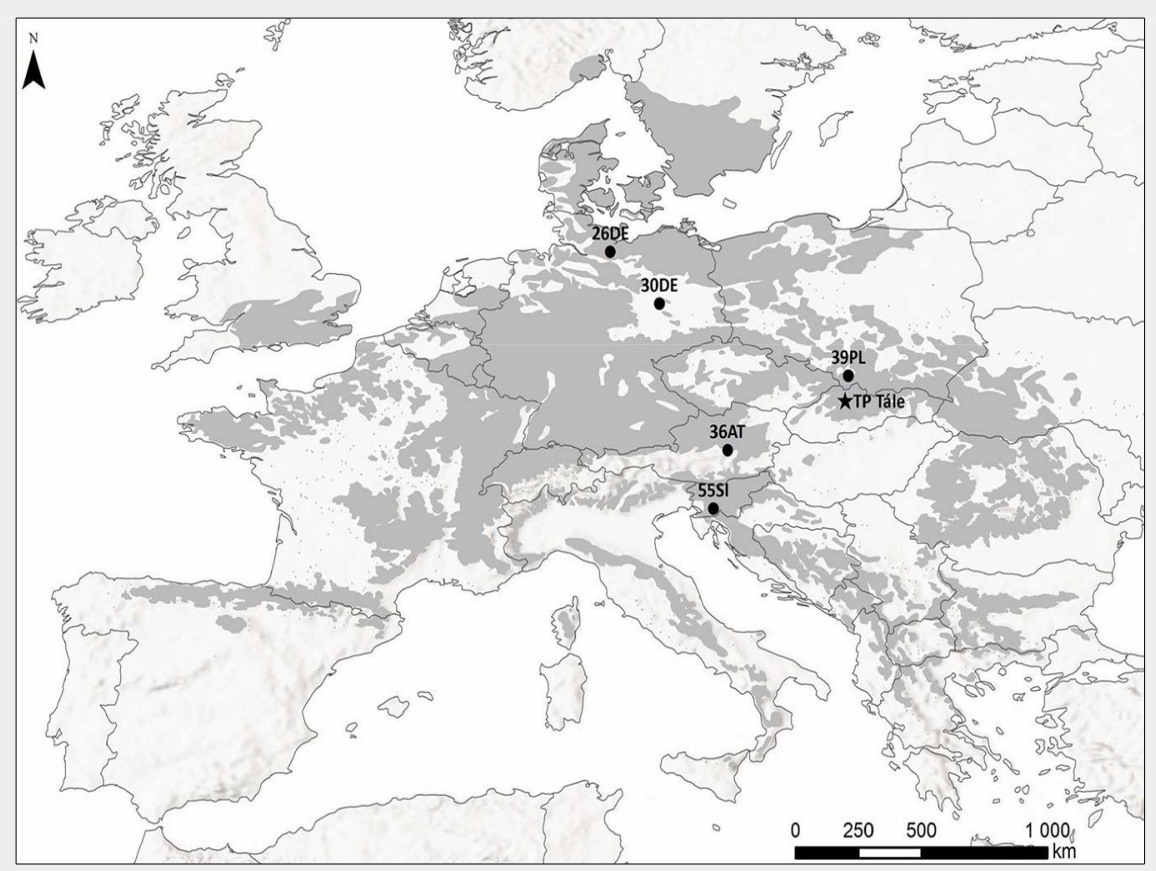

Fig. 1 - Origin of the tested provenances (circles) and the trial plot Tále (Central Slovakia, indicated by a star). The grey area represents the potential natural range of Fagus sylvatica in Europe (adapted from EUFORGEN 2015 - http://www.euforgen.org). the Slovenian glacial refugium to minimize the differences caused by the neutral evolutionary processes. All of the measurements were done on the same set of three individuals from two randomly selected blocks for each provenance. The experiment was carried out to study the physiological status of beech provenances via photosynthesis efficiency (using gasometry and chlorophyll $a$ fluorescence kinetics) and stomatal characteristics.

\section{Chlorophyll a fluorescence/Rapid Light Curves (RLCS)}

Parameters of chlorophyll $a$ fluorescence were recorded on three leaves per provenance in two replicates, using a portable chlorophyll fluorometer MINI-PAM ${ }^{\circledast}$ (Heinz Walz $\mathrm{GmbH}$, Germany). RLCs were measured automatically under the control of an internal programme. The actinic illumination was applied in eight steps, with light intensities increasing from 38 to $616 \mu \mathrm{mol}$ (photon) $\mathrm{m}^{-2} \mathrm{~s}^{-1}$ and duration of $10 \mathrm{~s}$. The illumination periods were separated by a o.8-s saturating flash from a white halogen lamp (2000-3000 $\mathrm{mmol}$ [photon] $\mathrm{m}^{-2} \mathrm{~s}^{-1}$ ). The following parameters were determined and/or calculated in RLCs measurements: (i) effective quantum yield of the PSII $\left(\Phi_{\mathrm{PSII}}=\Delta \mathrm{F} / \mathrm{F}_{\mathrm{m}}^{\prime}\right)$; (ii) coefficient of photochemical quenching ( $\mathrm{qP}$ - Genty et al. 1989, Zivcak et al. 2013); (iii) coefficient of nonphotochemical quenching ( $\mathrm{qN}$ ); and (iv) non-photochemical quenching (NPQ). All above parameters are indicators of excess light energy and heat-dissipation of excitation energy in the antenna system (Zivcak et al. 2013). The RLCs were quantified using: (i) the initial slope for RLCs of $\Phi_{\mathrm{PS} \|}$ and $\mathrm{qP}$ - slopes were evaluated by direct calculation using linear regression of four initial data points; and (ii) value of the end point - measured at $616 \mu \mathrm{mol}$ (photon) $\mathrm{m}^{-2} \mathrm{~s}^{-1}$ PAR - for RLCS of NPQ and $q N$.

\section{Stomatal characteristics}

Leaf samples were harvested from the sunny part of the upper third of the crown. Stomatal imprints were taken from six leaves per provenance using the colloid method. A thin coat of colourless nail polish was applied on the abaxial leaf side. After drying, the polish was peeled off using transparent tape and was stuck on a micro- 
scopic slide. All of the imprints were taken from the middle part of the leaf to avoid possible variation between the leaf base and tip (Bresson et al. 2011). The imprints were visualized using the light microscope Olympus $\mathrm{BX}_{50} \mathrm{O}^{\circledast}$ connected with the digital camera Canon DS126491 ${ }^{\circledR}$ (Canon Inc., Japan) and were evaluated using the software for picture analyses NIS Elements AR 3.0 (Laboratory Imaging, Czech Republic). Stomatal density (SD), length of guard cells $\left(L_{A}\right)$ and potential conductance index $(P C l)$ were determined. Stomatal density was counted from two $500 \times 500 \mu \mathrm{m}$ leaf areas at $20 \times 10$ magnification and converted into $\mathrm{mm}^{2}$ of leaf area. For the assessment of guard cells length, 15 stomata per imprint were chosen at the magnification of $40 \times 10$. The potential conductance index was calculated according to Holland \& Richardson (2009) using the following relationship: $\mathrm{PCl}=L_{\mathrm{A}}{ }^{2} \cdot S \mathrm{SD} \cdot 10^{-4}$.

\section{Gas exchange}

Leaf gas exchange measurements were carried out using the gasometric system Li$6400 X T^{\circledast}$ equipped with the chamber fitted with 6400-02B LED light source (LI-COR Biosciences, USA). Measurements were performed on three leaves per three trees per provenance in two replicates (18 leaves per provenance). All of the measurements were taken before the midday depression of photosynthesis appeared, on fully expanded leaves around $2 \mathrm{~m}$ above the ground. The leaves were exposed to a $\mathrm{CO}_{2}$ concentration of $385 \mu \mathrm{mol} \mathrm{mol}{ }^{-1}$ and the saturating PAR of $1300 \mu \mathrm{mol} \mathrm{m} \mathrm{m}^{-2} \mathrm{~s}^{-1}$. Gas exchange was measured at the air temperature in the chamber at $20.5 \pm 0.5^{\circ} \mathrm{C}$. The values were evaluated after a short adaptation period when the $\mathrm{CO}_{2}$ assimilation values remained stable. $\mathrm{CO}_{2}$ assimilation rate $(A)$, stomatal conductance $\left(g_{s}\right)$ and transpiration rate $(E)$ were determined.

\section{Data analysis}

The obtained data were processed using the statistical program STATISTICA ${ }^{\oplus}$ (StatSoft Inc., Tulsa, OK, USA). Prior to the statistical tests, the normal distribution of the data was tested. Because the distributions of several physiological parameters deviated from the normal distribution, data were square-root transformed. Differences in the measured parameters among provenances were tested using ANOVA, and pairwise contrasts were tested using Tukey's post-hoc tests with $\alpha=0.05$. For the assessment of altitudinal and climatic trends, provenance averages were fitted to linear regression models with the altitude and climate characteristics of their sites of origin.

\section{Results}

\section{Chlorophyll a fluorescence/RLCs}

We found differences among the studied provenances related to the course of $R L C_{\Phi P S I I}$ (slope of $R L C_{\Phi P S I}$ - Fig. 2a, Fig. 3a) as well as $R L C_{q p}$ (slope of $R L C_{q p}-$ Fig. $2 b$, Fig. 3b). From the point of view of altitude, the response of the provenance originating from the highest altitude (36AT, $1100 \mathrm{~m}$ a.s.l.) deviated from those of the other studied provenances (Fig. 2a, Fig. 2b, Fig. 3a, Fig. 3b), but the responses were not consistent along the altitudinal gradient. However, in connection with the dissipation of energy by heat (NPQ), the provenances from high altitudes 36AT and 55SI (1100 and $1040 \mathrm{~m}$ a.s.l., respectively) showed the lowest capability. A higher ability for the dissipation of energy by heat was recorded for populations $26 \mathrm{DE}$ and $39 \mathrm{PL}$ originating from the lower part of the altitudinal range of the studied provenances (Fig. 2c, Fig. 2d, Fig. 3c, Fig. 3d). The effect of precipitation regime at the sites of origin was also not confirmed. However, slight increases of the $\Phi_{\mathrm{PSII}}$ and $\mathrm{qP}$ along the gradient of the mean annual temperature and the temperature during the vegetation season were recorded.

\section{Stomatal characteristics}

Overall, we found a significant effect of altitude on all of the stomatal traits (Tab. 2). The mean stomatal density $(S D)$ gradually increased with altitude $\left(R^{2}=0.782\right.$; $P \leq 0.05$ ), however, the differences between the provenances were not statistically significant due to a high variability (Fig. 4a). The Slovenian provenance 55SI $(1040 \mathrm{~m}$ a.s.I.) reached the highest value of the $S D$ (on average, $258.7 \pm 33.7$ stomata $\mathrm{mm}^{-2}$ ). A significant increase along the altitudinal gradient $\left(R^{2}=0.932 ; P \leq 0.01\right)$ was also observed in the potential conductance indices increasing from $12.7 \pm 2.0$ for $26 \mathrm{DE}$ to $16.7 \pm$ 3.1 for 36AT. A marginally significant in-

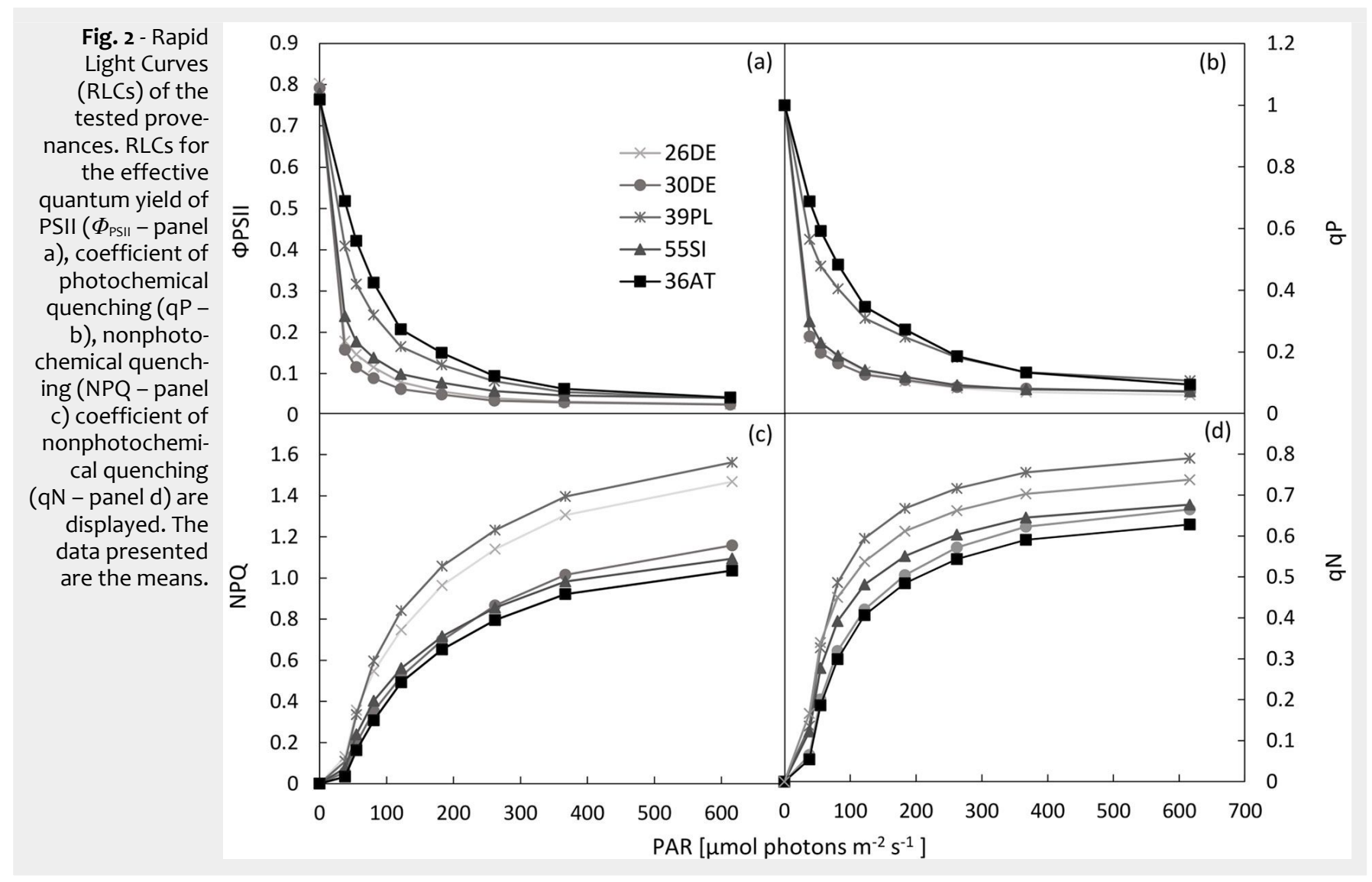




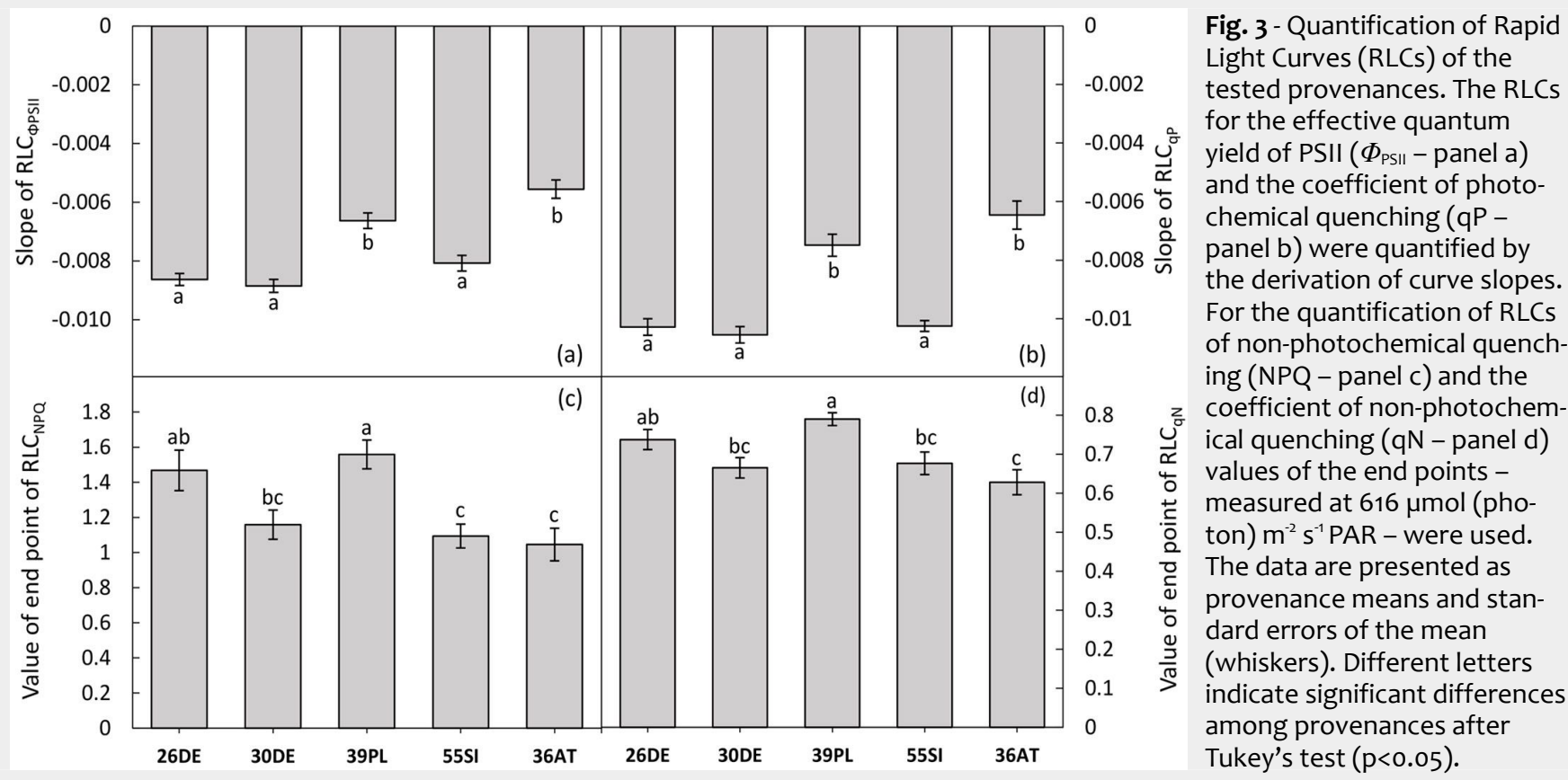

crease in the guard cell lengths was found $\left(R^{2}=0.7327 ; P \leq 0.10\right)$, with values ranging from $23.9 \pm 2.5 \mu \mathrm{m}$ for $30 \mathrm{DE}$ up to $25.9 \pm$ $4.4 \mu \mathrm{m}$ for 36AT. Moreover, analysis of variance confirmed that the provenance from Austria 36AT achieved the significantly highest values for both parameters (Fig. 4b, Fig. 4c). A similar pattern of reaction was also observed in relation to precipitation regime of the sites of origin (Tab. 2). Significant or at least marginally significant effects of the annual precipitation or the precipitation during the vegetation season on all of the monitored parameters were observed. Moreover, we noticed a negative effect of increasing mean annual temperature and mean temperature during the vegetation season on the length of guard cells $\left(R^{2}=0.823 ; P \leq 0.05\right.$ and $R^{2}=0.873$; $P \leq 0.05$, respectively).

\section{Gas exchange characteristics}

Based on the analysis of variance, we recorded statistically significant differences among provenances (Fig. 5a, Fig. 5b, Fig. $5 \mathrm{C}$ ) in terms of $\mathrm{CO}_{2}$ assimilation rate values, stomatal conductance and transpiration. Overall, we found a linear increase along the altitudinal gradient for all of the monitored traits. However, a significant linear trend of altitude was found only for the $\mathrm{CO}_{2}$ assimilation rate $\left(\mathrm{R}^{2}=0.877 ; \mathrm{P}=0.05\right)$.
We also recorded similar trends in relation to mean annual precipitations of the sites of origin $\left(R^{2}=0.897 ; P \leq 0.05\right)$ and to the precipitation during the vegetation season $\left(R^{2}=0.7327 ; P \leq 0.10\right)$. However, increasing mean annual temperature and mean temperature during the vegetation season had significant negative effects only on the stomatal conductance $\left(R^{2}=0.948 ; P \leq 0.01\right.$ and $R^{2}=0.886 ; P \leq 0.05$, respectively) and the transpiration $\left(R^{2}=0.857 ; P \leq 0.05\right.$ and $R^{2}=0.772 ; P \leq 0.05$, respectively). The Austrian provenance 36AT (1100 m a.s.l.) generally displayed the highest values of $\mathrm{CO}_{2}$ assimilation rate $\left(6.92 \mu \mathrm{mol} \mathrm{CO}_{2} \mathrm{~m}^{-2} \mathrm{~s}^{-1}\right)$, stomatal conductance $\left(0.15 \mathrm{~mol} \mathrm{CO}_{2} \mathrm{~m}^{-2} \mathrm{~s}^{-1}\right)$

Tab. 2 - Linear regressions of the provenance averages of measured parameters against the altitude and climatic traits of their origin. (A): assimilation rate $\left(\mu \mathrm{mol} \mathrm{m} \mathrm{m}^{-2}\right)$; $\left(\mathrm{g}_{\mathrm{s}}\right)$ : stomatal conductance $\left(\mu \mathrm{mol} \mathrm{m} \mathrm{m}^{-2} \mathrm{~s}^{-1}\right) ;(E)$ : transpiration rate $\left(\mu \mathrm{mol} \mathrm{m}^{-2} \mathrm{~s}^{-1}\right)$; (SD): stomatal density (stomata $\left.\mathrm{mm}^{-2}\right) ;\left(L_{A}\right)$ : length of guard cells $(\mu \mathrm{m}) ;(P C l)$ : potential conductance index; (RLC $\left.C_{\Phi P S I}\right)$ : initial slope of RLC $C_{\Phi P S I}$; $\left(R L C_{q P}\right)$ : initial slope of $R L C_{q p} ;\left(R L C_{N P Q}\right)$ : NPQ measured at PAR of $616 \mu \mathrm{mol}$ (photon) $\mathrm{m}^{-2} \mathrm{~s}^{-1} ;\left(R L C_{\mathrm{qN}}\right)$ : $\mathrm{qN}$ measured at PAR of $616 \mu \mathrm{mol}$ (photon) $\mathrm{m}^{-2} \mathrm{~s}^{-1} ;(A L T)$ : altitude; $\left(\mathrm{P}_{\mathrm{A}}\right)$ : mean annual precipitation; $\left(\mathrm{P}_{59}\right)$ : mean amount of precipitation during vegetation season; $\left(\mathrm{T}_{\mathrm{A}}\right)$ : mean annual temperature; $\left(T_{59}\right)$ : mean temperature during vegetation season; $\left(^{*}\right)$ : $p \leq 0.05 ;(* *): p \leq 0.01 ;(1)$ : marginally significant at $\mathrm{p} \leq 0.10$; (ns): non-significant.

\begin{tabular}{|c|c|c|c|c|c|c|c|c|c|c|c|}
\hline \multirow{2}{*}{ Variable } & \multirow{2}{*}{ Parameter } & \multicolumn{3}{|c|}{ Gas Exchange } & \multicolumn{3}{|c|}{ Stomatal Traits } & \multicolumn{2}{|c|}{ RLCs Initial Slope } & \multicolumn{2}{|c|}{ RLCs End Point } \\
\hline & & $A$ & $\mathrm{gs}_{\mathrm{s}}$ & $E$ & $S D$ & $L A$ & $\mathrm{PCl}$ & $\mathrm{RLC}_{\text {ФPSII}}$ & $\mathrm{RLC}_{\mathrm{qP}}$ & $\mathrm{RLC}_{\mathrm{NPQ}}$ & $\mathrm{RLC}_{\mathrm{qN}}$ \\
\hline \multirow{3}{*}{$\begin{array}{l}\text { ALT } \\
\text { (m a.s.l.) }\end{array}$} & Slope & 0.0018 & ns & $\mathrm{ns}$ & 0.0351 & 0.0015 & 0.004 & ns & ns & ns & ns \\
\hline & $\mathrm{R}^{2}$ & 0.877 & ns & ns & 0.787 & 0.733 & 0.932 & ns & ns & ns & ns \\
\hline & Prob & $0.0192^{*}$ & ns & ns & $0.045^{*}$ & 0.0641 & $0.008^{* *}$ & ns & ns & ns & ns \\
\hline \multirow{3}{*}{$\begin{array}{l}P_{A} \\
(\mathrm{~mm})\end{array}$} & Slope & 0.0028 & ns & ns & 0.052 & ns & 0.0056 & ns & ns & ns & ns \\
\hline & $\mathrm{R}^{2}$ & 0.897 & ns & ns & 0.775 & ns & $0.902^{(1)}$ & ns & ns & ns & ns \\
\hline & Prob & $0.014^{*}$ & ns & ns & $0.049^{*}$ & ns & $0.036^{*}$ & ns & ns & ns & ns \\
\hline \multirow{3}{*}{$\begin{array}{l}P_{59} \\
(\mathrm{~mm})\end{array}$} & Slope & 0.0057 & 0.0001 & 0.001 & ns & 0.0043 & 0.0106 & ns & ns & ns & ns \\
\hline & $\mathrm{R}^{2}$ & 0.924 & 0.676 & 0.697 & ns & 0.7083 & 0.708 & ns & ns & ns & ns \\
\hline & Prob & $0.009^{* *}$ & 0.0881 & 0.0781 & ns & 0.0741 & 0.0741 & ns & ns & ns & ns \\
\hline \multirow{3}{*}{$\begin{array}{l}\mathrm{T}_{\mathrm{A}} \\
\left({ }^{\circ} \mathrm{C}\right)\end{array}$} & Slope & ns & -0.0086 & -0.0729 & ns & -0.3197 & ns & -0.0006 & -0.0008 & ns & ns \\
\hline & $\mathrm{R}^{2}$ & ns & 0.948 & 0.857 & ns & 0.823 & ns & 0.922 & 0.89 & ns & ns \\
\hline & Prob & ns & $0.005^{* *}$ & $0.024^{*}$ & ns & $0.034^{*}$ & ns & $0.010^{* *}$ & $0.016^{*}$ & ns & ns \\
\hline \multirow{3}{*}{$\begin{array}{l}\mathrm{T}_{59} \\
\left({ }^{\circ} \mathrm{C}\right)\end{array}$} & Slope & ns & -0.0087 & -0.0727 & ns & -0.3458 & ns & -0.0006 & -0.0007 & ns & ns \\
\hline & $\mathrm{R}^{2}$ & ns & 0.886 & 0.772 & ns & 0.873 & ns & 0.846 & 0.798 & ns & ns \\
\hline & Prob & ns & $0.017^{*}$ & $0.050^{*}$ & ns & $0.020^{*}$ & ns & $0.027^{*}$ & $0.041^{*}$ & ns & ns \\
\hline
\end{tabular}




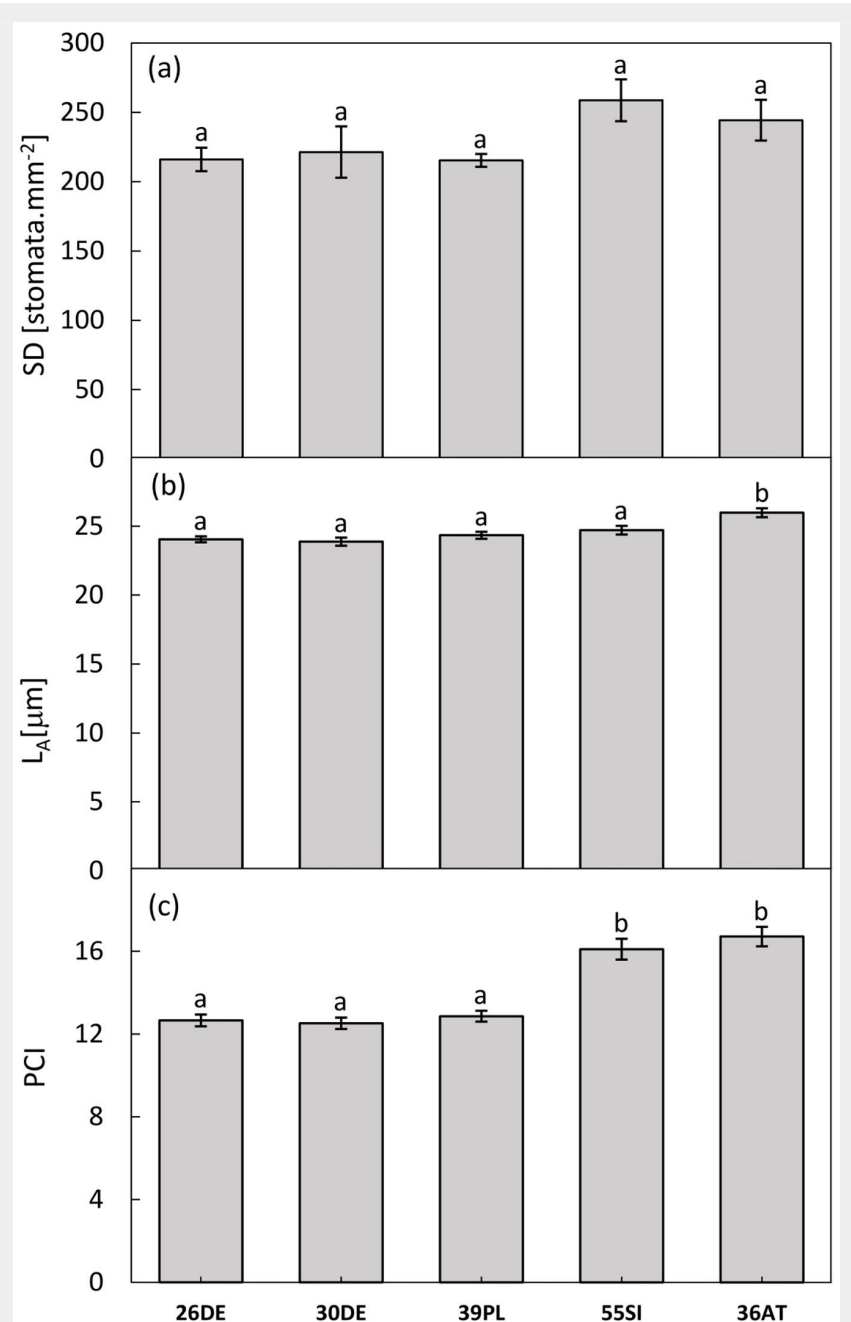

Fig. 4 - Stomatal traits of the tested provenances. Stomatal density (SD - panel a), guard cell lengths $\left(L_{A}-\right.$ panel b) and potential conductance indices $(P C l-$ panel $c)$ are displayed. The bar chart represents the provenance means and standard errors of the mean. The different letters indicate that values differ significantly among provenances after Tukey's test $(P<0.05)$.

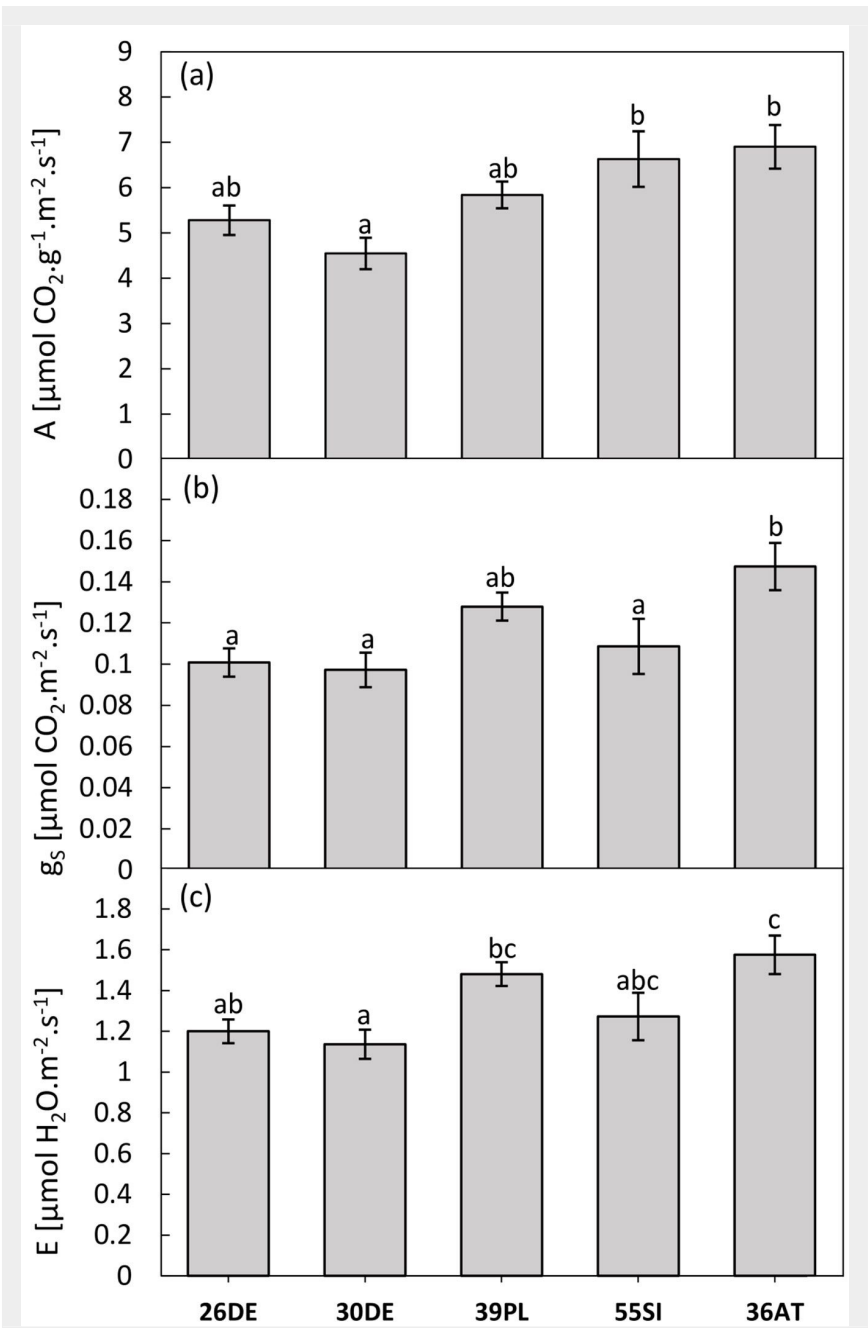

Fig. 5 - Parameters of gas exchanges of the tested provenances. $\mathrm{CO}_{2}$ assimilation rate $(A-$ panel a), stomatal conductance $\left(g_{s}-\right.$ panel $\left.b\right)$ and transpiration ( $E$ - panel $\left.c\right)$ are displayed. The bar chart represents the provenance means and standard errors of the mean. The different letters indicate that values differ significantly among provenances after Tukey's test $(P<0.05)$. and transpiration ( $1.58 \mathrm{~mol} \mathrm{H}_{2} \mathrm{O} \mathrm{m}^{-2} \mathrm{~s}^{-1}$ ). In comparison, the least-vital provenance 30DE (140 $\mathrm{m}$ a.s.l.) reached approximately $34 \%$ lower values of $A\left(4.55 \mu \mathrm{mol} \mathrm{CO} \mathrm{m}^{-2} \mathrm{~s}^{-1}\right)$ and $\mathrm{g}_{\mathrm{s}}\left(0.1 \mathrm{~mol} \mathrm{CO}_{2} \mathrm{~m}^{-2} \mathrm{~s}^{-1}\right)$, and approximately $28 \%$ lower values of $E\left(1.13 \mathrm{~mol} \mathrm{H}_{2} \mathrm{O}\right.$ $\left.\mathrm{m}^{-2} \mathrm{~s}^{-1}\right)$.

\section{Discussion}

Provenance trials provide the basis to observe the response of provenances to different environmental conditions (Matyas 1994). In our study, we try to determine levels of adaptation of beech provenances to climate conditions at the trial site in relation to the climate of origin. Several recent studies have focused on the suitability of environmental conditions at different altitude ranges of plant species (Schoettle \& Rochelle 2000, Holland \& Richardson 2009) and also on the effect of stress factors differing among plots (Jägerbrand \& Kudo 2016). The divergence between populations is driven by the differences in the se- lective pressure imposed by different ecological environments, neutral evolutionary processes or both (Still et al. 2005); in our case, when the distances between the studied populations are quite large, the role of neutral factors such as isolation by distance or genetic drift may be important, but we tried to minimize such effects by choosing populations originating from the same glacial refugium (Slovenia/Istria - Magri et al. 2006). The dynamic and thermodynamic processes at high altitudes lead to the formation of regional-scale atmospheric circulation with wind systems, temperatures and precipitation regimes, etc., differing from general precipitation and negative temperature gradient along the gradient of altitude. Our results showed that beech provenances originating from altitudinal extremes are substantially different in most ecophysiological and morphological traits. The provenances originating from localities with lower amounts of annual precipitation and higher tempera- tures, i.e., 26DE and 30DE, responded very sensitively to the conditions of the trial plot. On the contrary, the provenances $55 \mathrm{SI}$ and 36AT originating from cool and wet sites show favourable values of the measured physiological parameters. As reported by Bohn (2004) and Rose et al. (2009), this result may be influenced by a smaller shift in terms of climate between the site of origin and the trial plot. These observations are also very closely related to increasing continentality influencing water availability under the conditions of the trial plot, where the populations originating from areas with a subcontinental climate (i.e., 26DE, 30DE, 39PL) appear as highly responsive. Several monitored parameters showed an increase with increasing altitude and relations to climatic gradients. These reaction patterns are most probably acquired by genetically-driven responses to conditions of the origin sites and are fixed across the life span of each individual (Premoli \& Brewer 2007). 
The methods of evaluation of chlorophyll a fluorescence (fast and slow kinetics of chlorophyll $a$ fluorescence) are rapid, nondestructive and non-invasive, and helpful in the detection of changes in the photosynthetic process caused by abiotic stress before visible signs of deterioration are apparent to the naked eye (Swoczyna et al. 2010). These methods are generally used to assess plant vitality and performance in relation to different conditions (Gallé \& Feller 2007, Zivcak et al. 2014, Pšidová et al. 2015, Kalaji et al. 2016). Despite the fact that none of the chlorophyll $a$ fluorescence parameters exhibited a smooth trend along the altitudinal gradient, some clear climatic trends or differences between contrasting groups of provenances were observed. These trends correspond well with the observed photosynthetic performance $\left(\mathrm{CO}_{2}\right.$ exchange) and stomatal traits. The results of chlorophyll a fluorescence assessment indicated the best photosynthetic performance in the conditions of the trial plot for the provenances $55 \mathrm{SL}$ and $36 \mathrm{AT}$ originating from cooler climates. Moreover, substantial downregulation of $\Phi_{\mathrm{PS} I}$ and $\mathrm{qP}$ was recorded for the $26 \mathrm{DE}$ provenance originating from warmer and drier climate compared to the 36AT provenance, which means that a large fraction of the absorbed irradiance was not utilized via photochemical reaction in the $26 \mathrm{DE}$ provenance. This result is confirmed by increasing NPQ levels for the 26DE provenance, indicating reduced electron flow (Chen et al. 2016). However, it is also known that higher values of NPQ indicate the ability of plants to mitigate the negative impact of stress conditions at the chloroplast level through the dissipation of excessive excitation energy (Ismail et al. 2014, Hazrati et al. 2016). Plants display a variety of physiological adaptations to prevailing changing environmental conditions in different ways at the chloroplast level.

The ability of plants to regulate the exchange of water vapour and $\mathrm{CO}_{2}$ through stomata is an important feature characterizing the status of plants in their environment. Effective stomata control is important for plant growth and survival, especially when water supply is limited, but also in terms of their competitive capabilities and the expansion of space in which they are able to grow (Tardieu \& Davies 1993, Barber et al. 2004, Alves et al. 2007). Moreover, stomatal control in European beech is often unable to maintain the shoot water potential above the critical limit, thereby preventing the loss of hydraulic conductivity (Aranda et al. 2000, Fotelli et al. 2001). The increased stomatal density and stomatal size are considered to improve the plant efficiency of $\mathrm{CO}_{2}$ uptake. However, their decrease might reflect a decrease in the relative air humidity and hence it could be associated with plant water-saving strategy (Schoettle \& Rochelle 2000, McElwain 2004).

Several studies reported changes in stom- atal traits with increasing altitude in various plant species including beech; $\mathrm{PCl}$, guard cell length or stomatal density were observed to increase with altitude (Hovenden \& Brodribb 2000, Kouwenberg et al. 2007, Bresson et al. 2009, Paridari et al. 2013, Wang et al. 2014), presumably compensating for a decrease of $\mathrm{CO}_{2}$ partial pressure, which limits photosynthetic potential across altitudinal gradients, shorter growing seasons and/or increasing UV radiation (Woodward \& Bazzaz 1988, Kouwenberg et al. 2007, Wang et al. 2014). The increase in stomatal density and index with altitude could be also result of opening up of the higher altitude landscape, which increases the amount of intercepted radiation (Hovenden \& Brodribb 2000). Lower precipitation and water availability in lower altitudes strongly influence stomatal density and epidermal cell density as well (Lake et al. 2002). This was confirmed by Pyakurel \& Wang (2014) who recorded higher stomatal density by birch provenances originating from areas with higher annual precipitation and lower temperatures. However, mentioned studies focused on phenotypic stomatal variation along vertical transects within one mountain range. Therefore, in contrast with provenance trials, the conditions of growth are unequal, and the differences among populations might be influenced by largescale variation of environmental factors. Although a study on the stomatal analysis of beech in a provenance trial was also published (Stojnić et al. 2015), the authors focused on how stomatal traits (stomatal density, width of stomatal pore, potential conductance index, relative stomatal pore surface and length of guard cells) of beech provenances react to drought stress during two years characterized by contrasting weather conditions. Similarly, Xu \& Zhou (2008) studied the response of stomatal traits in Leymus chinensis to a large range of water statuses. Although these studies suggest the possibility of a plastic response of populations toward changes in soil water regime influenced by the prevailing weather, the absence of geographic and climatic trends did not provide an answer to the question whether stomatal characteristics are affected only by the current environmental conditions (acclimation to higher precipitation regime and lower temperatures at higher altitudes), or whether environmental conditions of origin drive adaptation at the population level. However, significant climatic trends in stomatal traits revealed in our study support the assumption that genetic effects on stomata traits do exist.

Early studies noted a positive correlation between the leaf stomatal density and stomatal conductance $g_{s}$ (Woodward \& Bazzaz 1988, Xu \& Zhou 2008). Stomatal conductance is a primary determinant of net carbon balance and growth of plant species, and because of its influence on water loss through transpiration, stomatal conductance determines the water balance of a plant. Moreover, plants with higher $g_{s}$ values may be able to assimilate $\mathrm{CO}_{2}$ more rapidly than those with a lower conductance (Bresson et al. 2011). Our results showed that $\mathrm{CO}_{2}$ assimilation rate $(A)$, stomatal conductance $\left(g_{s}\right)$ and transpiration $(E)$ increased with increasing altitude. These trends were documented by Kohout \& Read (2006), Premoli \& Brewer (2007) and Zhang et al. (2005) as well. Körner (2007) suggested that trees carry out a relatively high level of photosynthesis to compensate for extreme environmental conditions and short growing season at high altitudes. This hypothesis was confirmed also by Bresson et al. (2009), who noted that the $\mathrm{CO}_{2}$ assimilation rate increased significantly with increasing altitude, approximately $2.8 \mu \mathrm{mol} \mathrm{CO} \mathrm{Cm}^{-2} \mathrm{~s}^{-1}$ per $1000 \mathrm{~m}$ for beech. The small increase in maximum as similation rate at high altitude may be attributed to a slight increase in stomatal conductance, implying an increase in $\mathrm{CO}_{2}$ diffusion into the leaf. Premoli \& Brewer (2007) showed that $\mathrm{CO}_{2}$ assimilation rates were $40 \%$ higher for high-altitude plants in the field than those for low-altitude plants in Nothofagus pumilio, although they assumed that assimilation was under genetic control. Moreover, our results pointed to positive effect of increasing amount of precipitation and negative effect of increasing temperature to gas exchange. Also, the highest values of $A_{\max }$ and $g_{s}$ were recorded in Picea glauca trees growing on the site with the higher precipitation and lower mean annual temperature (Benomar et al. 2016).

\section{Conclusion}

For the stability and productivity of future forests, it is particularly important to choose suitable provenances that could be used as seed sources for future reforestation programmes. Based on our results, we may conclude that provenances from cooler and wetter climate, originating from the central part of beech distribution (i.e., conditions roughly similar to the environment of the trial plot Tále) showed higher physiological performance under the conditions of Central Europe compared to the provenances that have experienced a larger shift in climate between the site of origin and the trial plot. The knowledge of physiological responses of beech to environmental conditions in direct response to its geographical origin will help to evaluate the impact of climate changes on populations of the forest tree and mitigate these changes.

\section{Acknowledgements}

$L D, D G$ conceived the ideas and designed the study; JK, DK, GJ, EP, AK, KS carried out the measurements, processed and interpreted of data; JK, AK wrote the first version of manuscript, and all of the authors contributed critically to the drafts and gave final approval for publication. 
We would like to thank Tibor Priwitzer and Peter Petrík for their technical assistance during this experiment and $\mathrm{K}$. Willingham for language correction.

The experiment was supported by the grant of the Slovak Agency for Research and Development APVV-0135-12 (0.2), the grant of the Slovak Grant Agency for Science VEGA 0034-14 (0.8).

\section{List of Abbreviations}

The following abbreviations have been used throughout the paper:

- RLC: rapid light curve of chlorophyll a fluorescence;

- $\Phi_{\text {PSII: }}$ effective quantum yield of PSII (yield, $\Delta \mathrm{F} / \mathrm{F}_{\mathrm{m}}^{\prime}$ );

- qP: coefficient of photochemical quenching;

- qN: coefficient of non-photochemical quenching;

- NPQ: non-photochemical quenching;

- RLC $C_{\Phi P S I}$ : rapid light curve of the effective quantum yield of PSII;

- $R L C_{q p}$ : rapid light curve of the coefficient of photochemical quenching;

- $R L C_{q N}$ : rapid light curve of the coefficient of non-photochemical quenching;

- $\mathrm{RLC}_{\mathrm{NPQ}}$ : rapid light curve of the non-photochemical quenching;

- SD: stomatal density;

- $L_{A}$ : length of stomata guard cells;

- $P C l$ : potential conductance index, calculated as $P C l=L_{A}^{2} \cdot S D \cdot 10^{-4}$;

- A: assimilation rate;

- gs: stomatal conductance;

- E: transpiration rate.

\section{References}

Ackerly DD, Dudley SA, Sultan SE, Schmitt J, Coleman JS, Linder CR, Sandquist DR, Geber MA, Evans AS, Dawson TE, Lechowicz MJ (2000). The evolution of plant ecophysiological traits: recent advances and future directions new research addresses natural selection, genetic constraints, and the adaptive evolution of plant ecophysiological traits. Bioscience 50 : 979-995. - doi: 10.1641/0006-3568(2000)050[09 79:TEOPET]2.0.CO;2

Alves ES, Moura BB, Domingos M (2007). Structural analysis of Tillandsia usneoides L. exposed to air pollutants in São Paulo City-Brazil. Water, Air, and Soil Pollution 189: 61-68. - doi: 10.1007/ s11270-007-9555-1

Aranda I, Gil L, Pardos JA (2000). Water relations and gas exchange in Fagus sylvatica L. and Quercus petraea (Mattuschka) Liebl. in a mixed stand at their southern limit of distribution in Europe. Trees 14: 344-352. - doi: 10.1007/s004 680050229

Barber JL, Thomas GO, Kerstiens G, Jones KC (2004). Current issues and uncertainties in the measurement and modelling of air-vegetation exchange and within-plant processing of POPs. Environmental Pollution 128: 99-138. - doi: 10.1016/j.envpol.2003.08.024

Benomar L, Lamhamedi MS, Rainville A, Beaulieu J, Bousquet J, Margolis HA (2016). Genetic adaptation vs. ecophysiological plasticity of photosynthetic-related traits in young Picea glauca trees along a regional climatic gradient. Fron- tiers in Plant Science 7: 1-15. - doi: 10.3389/fpls. 2016.00048

Beuker E, Valtonen E, Repo T (1998). Seasonal variation in the frost hardiness of Scots pine and Norway spruce in old provenance experiments in Finland. Forest Ecology and Management 107: 87-98. - doi: 10.1016/So378-1127(97) 00344-7

Bohn (2004). Karte der natürlichen vegetation Europas [Map of the natural vegetation of Europe]. In: Proceeding of the Meeting “Beiträge zum Fachkolloquium”. Halle (Germany) 12 Mar 2001. Berichte des Landesamtes für Umweltschutz Sachsen-Anhalt, Halle, Germany, pp. 4-13. [in German]

Bresson CC, Kowalski AS, Kremer A, Delzon S (2009). Evidence of altitudinal increase in photosynthetic capacity: gas exchange measurements at ambient and constant $\mathrm{CO}_{2}$ partial pressures. Annals of Forest Science 66: 505505. - doi: 10.1051/forest/2009027

Bresson CC, Vitasse Y, Kremer A, Delzon S (2011). To what extent is altitudinal variation of functional traits driven by genetic adaptation in European oak and beech? Tree Physiology 31: 111. - doi: 10.1093/treephys/tpro84

Bussotti F, Pollastrini M, Holland V, Brüggemann $W$ (2015). Functional traits and adaptive capacity of European forests to climate change. Environmental and Experimental Botany 111: 91-113. doi: 10.1016/j.envexpbot.2014.11.006

Chen YE, Liu WJ, Su YQ, Cui JM, Zhang ZW, Yuan M, Zhang HY, Yuan S (2016). Different response of photosystem II to short and long-term drought stress in Arabidopsis thaliana. Physiologia Plantarum 158: 225-235. - doi: 10.1111/ppl. 12438

Clausen J, Keck DD, Hiesey WM (1939). The concept of species based on experiment. American Journal of Botany 26: 103-106. - doi: 10.2307/ 2436717

Fotelli MN, Geler A, Peuke AD, Rennenberg H (2001). Drought affects the competitive interactions between Fagus sylvatica seedlings and an early successional species, Rubus fruticosus: responses of growth, water status and $\delta^{13} \mathrm{C}$ composition. New Phytologist 151: 427-435. doi: 10.1046/j.1469-8137.2001.00186.x

Gallé A, Feller U (2007). Changes of photosynthetic traits in beech saplings (Fagus sylvatica) under severe drought stress and during recovery. Physiologia Plantarum 131: 412-421. - doi: 10.1111/j.1399-3054.2007.00972.x

Genty B, Briantais JM, Baker NR (1989). The relationship between the quantum yield of photosynthetic electron transport and quenching of chlorophyll fluorescence. Biochimica et Biophysica Acta - General Subjects 990: 87-92. doi: 10.1016/S0304-4165(89)80016-9

Gömöry D (2010). Geographic patterns in the reaction of beech provenances to transfer. In: Proceedings of the Workshop and MC Meeting of the COST Action E52 "Evaluation of Beech Genetic Resources for Sustainable Forestry". Thessaloniki (Greece) 5-7 May 2009, pp. 90-97. Gömöry D, Ditmarová L, Hrivnák M, Jamnická G, Kmet J, Krajmerová D, Kurjak D (2015). Differentiation in phenological and physiological traits in European beech (Fagus sylvatica L.). European Journal of Forest Research 134: 10751085. - doi: 10.1007/s10342-015-0910-2
Hamrick JL (2004). Response of forest trees to global environmental changes. Forest Ecology and Management 197: 323-335. - doi: 10.1016/j. foreco.2004.05.023

Hazrati S, Tahmasebi-Sarvestani Z, Modarres-Sanavy SAM, Mokhtassi-Bidgoli A, Nicola S (2016). Effects of water stress and light intensity on chlorophyll fluorescence parameters and pigments of Aloe vera L. Plant Physiology and Biochemistry 106: 141-148. - doi: 10.1016/j.plaphy.20 16.04.046

Holland N, Richardson AD (2009). Stomatal length correlates with elevation of growth in four temperate species. Journal of Sustainable Forestry 28: 63-73. - doi: 10.1080/10549810802 626142

Hovenden MJ, Brodribb TJ (2000). Altitude of origin influences stomatal conductance and therefore maximum assimilation rate in Southern Beech, Nothofagus cunninghamii. Australian Journal of Plant Physiology 27: 450-456. - doi: 10.1071/PP99195

Ismail IM, Basahi JM, Hassan IA (2014). Gas exchange and chlorophyll fluorescence of pea (Pisum sativum L.) plants in response to ambient ozone at a rural site in Egypt. The Science of the Total Environment 497- 498: 585-593. doi: 10.1016/j.scitotenv.2014.06.047

Jägerbrand AK, Kudo G (2016). Short-term responses in maximum quantum Yield of PSII (Fv/Fm) to ex situ temperature treatment of populations of Bryophytes originating from different sites in Hokkaido, Northern Japan. Plants 5: 22. - doi: 10.3390/plants5020022

Kalaji HM, Jajoo A, Oukarroum A, Brestic M, Zivcak M, Samborska IA, Cetner MD, Lukasik I, Goltsev V, Ladle RJ (2016). Chlorophyll a fluorescence as a tool to monitor physiological status of plants under abiotic stress conditions. Acta Physiologiae Plantarum 38 (4): 23. - doi: 10.1007/s11738-016-2113-y

Kohout M, Read J (2006). Instantaneous photosynthetic responses to temperature of deciduous and evergreen Nothofagus species. Australian Journal of Botany 54: 249-259. - doi: 10.1071/BT04175

Kouwenberg LLR, Kürschner WM, McElwain JC (2007). Stomatal frequency change over altitudinal gradients: prospects for paleoaltimetry. Reviews in Mineralogy and Geochemistry 66: 215-241. - doi: 10.2138/rmg.2007.66.9

Körner C (2007). The use of "altitude" in ecological research. Trends in Ecology and Evolution 22: 569-574. - doi: 10.1016/j.tree.2007.09.006

Lake JA, Woodward FI, Quick WP (2002). Longdistance $\mathrm{CO}_{2}$ signalling in plants. Journal of Experimental Botany 53: 183-193. - doi: 10.1093/ jexbot/53.367.183

Magri D, Vendramin GG, Comps B, Dupanloup I, Geburek T, Gömöry D, Latalowa M, Litt T, Paule L, Roure JM, Tantau I, Van Der Knaap WO, Petit RJ, De Beaulieu J-L (2006). Palaeobotanical and genetic data outline the quaternary history of European beech populations. New Phytologist 171: 199-222. - doi: 10.1111/j.1469-8137.2006.017 40.x

Matyas C (1994). Modeling climate change effects with provenance test data. Tree Physiology: 17: 797-804. - doi: 10.1093/treephys/14.7-89.797

McElwain JC (2004). Climate-independent pale- 
oaltimetry using stomatal density in fossil leaves as a proxy for $\mathrm{CO}_{2}$ partial pressure. Geology 32: 1017-1020. - doi: 10.1130/G20915.1

Nicotra AB, Atkin OK, Bonser SP, Davidson AM, Finnegan EJ, Mathesius $U$, Poot $P$, Purugganan MD, Richards $C L$, Valladares $F$, Van Kleunen $M$ (2010). Plant phenotypic plasticity in a changing climate. Trends in Plant Science 15: 684-692. doi: 10.1016/j.tplants.2010.09.008

Paridari IC, Jalali SG, Sonboli A, Zarafshar M, Bruschi P (2013). Leaf macro- and micro-morphological altitudinal variability of Carpinus betulus in the Hyrcanian forest (Iran). Journal of Forestry Research 24: 301-307. - doi: 10.1007/ s11676-013-0353-X

Premoli AC, Brewer CA (2007). Environmental genetically driven variation in ecophysiological traits of Nothofagus pumilio from contrasting elevations. Australian Journal of Botany 55: 585-591. - doi: 10.1071/BT06026

Pyakurel A, Wang JR (2014). Leaf morphological and stomatal variations in paper birch populations along environmental gradients in Canada. American Journal of Plant Sciences 5: 15081520. - doi: 10.4236/ajps.2014.511166

Pšidová E, Ditmarová L, Jamnická G, Kurjak D, Majerová J, Czajkowski T, Bolte A (2015). Photosynthetic response of beech seedlings of different origin to water deficit. Photosynthetica 53: 1-8. - doi: 10.1007/s11099-015-0093-6

Read QD, Moorhead LC, Swenson NG, Bailey JK, Sanders NJ (2014). Convergent effects of elevation on functional leaf traits within and among species. Functional Ecology 28: 37-45. - doi: 10.1111/1365-2435.12162

Rose L, Leuschner C, Köckemann B, Buschmann

$\mathrm{H}$ (2009). Are marginal beech (Fagus sylvatica

L.) provenances a source for drought tolerant ecotypes? European Journal of Forest Research 128: 335-343. - doi: 10.1007/s10342-009-0268-4 Schoettle AW, Rochelle SG (2000). Morphological variation of Pinus flexilis (Pinaceae), a birddispersed pine, across a range of elevations. American Journal of Botany 87: 1797-1806. - doi: $10.2307 / 2656832$

St Clair BJ, Howe GT (2007). Genetic maladaptation of coastal Douglas-fir seedlings to future climates. Global Change Biology 13: 1441-1454. doi: $10.1111 / j \cdot 1365-2486.2007 .01385 . x$

Still DW, Kim D-H, Aoyama N (2005). Genetic variation in Echinacea angustifolia along a climatic gradient. Annals of Botany 96: 467-477. doi: 10.1093/aob/mci199

Stojnić S, Orlović S, Trudić B, Zivković U, Von Wuehlisch G, Miljković D (2015). Phenotypic plasticity of European beech (Fagus sylvatica L.) stomatal features under water deficit assessed in provenance trial. Dendrobiology 73: 163-173 doi: $10.12657 /$ denbio.073.017

Swoczyna T, Kalaji HM, Pietkiewicz S, Borowski J, Zaras-Januszkiewicz E (2010). Monitoring young urban trees tolerance to roadside conditions by application of chlorophyll fluorescence technique. Zeszyty Problemowe Postepów Nauk Rolniczych 545: 303-309.

Tardieu F, Davies WJ (1993). Integration of hydraulic and chemical signalling in the control of stomatal conductance and water status of droughted plants. Plant, Cell and Environment 16: 341-349. - doi: 10.1111/j.1365-3040.1993.tboo 8 $80 . x$

Wang R, Yu G, He N, Wang Q, Xia F, Zhao N, Xu Z, Ge J (2014). Elevation-related variation in leaf stomatal traits as a function of plant functional type: evidence from Changbai Mountain, China. PLoS ONE 9 (12): e115395. - doi: 10.1371/journal. pone.0115395

Woodward FI, Bazzaz FA (1988). The responses of stomatal density to $\mathrm{CO}_{2}$ partial pressure. Journal of Experimental Botany 39: 1771-1781. doi: $10.1093 / \mathrm{jxb} / 39.12 .1771$

Wortemann R, Herbette S, Barigah TS, Fumanal B, Alia R, Ducousso A, Gömöry D, RoeckelDrevet P, Cochard H (2011). Genotypic variability and phenotypic plasticity of cavitation resistance in Fagus sylvatica L. across Europe. Tree Physiology 31: 1175-1182. - doi: 10.1093/treephys/ tpr101

Xu Z, Zhou G (2008). Responses of leaf stomatal density to water status and its relationship with photosynthesis in a grass. Journal of Experimental Botany 59: 3317-3325. - doi: 10.1093/jxb/ ern185

Zhang SB, Zhou ZK, Hu H, Xu K, Yan N, Li S (2005). Photosynthetic performances of Quercus pannosa vary with altitude in the Hengduan Mountains, southwest China. Forest Ecology and Management 212: 291-301. - doi: 10.1016/j. foreco.2005.03.031

Zivcak M, Brestic M, Balatova Z, Drevenkova P, Olsovska K, Kalaji HM, Yang X, Allakhverdiev SI (2013). Photosynthetic electron transport and specific photoprotective responses in wheat leaves under drought stress. Photosynthesis Research 117: 529-546. - doi: 10.1007/s11120-0139885-3

Zivcak M, Brestic M, Kalaji HM, Govindjee X (2014). Photosynthetic responses of sun- and shade-grown barley leaves to high light: is the lower PSII connectivity in shade leaves associated with protection against excess of light? Photosynthesis Research 119: 339-354. - doi: 10.1007/s11120-014-9969-8 